\title{
Mediation In Construction Industry?
}

\section{Zulhabri Ismail $^{1}$, Jamalunlaili Abdullah ${ }^{1}$, Padzil Fadzil Hassan $^{1}$ and Rosli Mohamad Zin ${ }^{1}$}

${ }^{1}$ Department of Building, Faculty of Architecture, Planning and Surveying, Universiti Technology MARA, 40450 Shah Alam Selangor Malaysia, zulhabri_ismail@yahoo.co.uk

\begin{abstract}
Private dispute resolution refers to settlement of disputes "other than litigation" which is not open to the public. This includes mediation, adjudication and arbitration. Of the three private dispute resolution methods, arbitration and mediation were promoted in the Malaysian construction industry. Notwithstanding the continuing reliance on litigation as the approach to solve construction disputes, arbitration was gradually accepted by the industry. As arbitration is a more favored approach, it was realized that arbitration can be adversarial. Therefore, a more "friendly" approach to solve disputes was needed to be considered. Consequently, mediation was introduced and promoted. However to date, its application has been poor. This paper presents the research which investigates what is currently the trend in mediation. It was developed on the premise that the poor response in adopting mediation as a form of private dispute resolution could be because mediation was poorly conceived and applied. A combined quantitative research method using the survey and qualitative research method using semi-structured interviews were adopted for the research. The variables which could impact on the application of mediation were also investigated. The findings suggested that, while mediation was generally considered appropriate there were concerns on the adequacy of its provisions and practice. Views on how this could be overcome were identified. The conclusions suggested the needs for the industry to re-learn its approach in the promotion and the application of mediation if it is to be more effective.
\end{abstract}

Keywords: Private dispute resolution, mediation, mixed methods and construction industry.

\section{Introduction}

Dispute is inevitable in construction projects and it can be regarded as endemic in the construction industry. Disputes can either be avoided from the start by way of efficient risk allocation and management or resolved once it is occurs. The former seems to be more suitable to avoid unnecessary time and cost. However, the latter may be practical for complex issues which require third party's interference (Edwards \& Shaoul, 2003). 
Dispute resolution can be divided into two main categories which are public and private. Public dispute resolution refers to the nature of litigation which focuses on the fair implications of private interactions but open to the public (Stitt, 2004; Forster \& Jivan, 2008).

Generally, there is no guarantee of privacy in litigations due to the publication of judgments in law journals. Comparatively, private dispute resolution refers to private mechanism in which parties' autonomy will play bigger roles in dispute resolution and confidentiality characteristic of the overall process. There are three method of private dispute resolution available in major standard form of construction contracts in Malaysia namely arbitration, which is the ultimate dispute resolution for construction disputes, mediation which has been around for more than ten years and the latest is adjudication which has been introduced in the Malaysian Institute of Architects (PAM) latest 2006 standard form of contract. This paper discusses on the application of mediation in the Malaysian construction industry in comparison to arbitration and how to further utilize and improve the stated method of private dispute resolution.

\section{Arbitration and mediation}

Arbitration refers to the process of dispute resolution carried out under the law of arbitration of any country in the world (Clause 3.4 Rules of the Institute of Arbitrators Malaysia). It is an adversarial private dispute resolution with final and binding resolution (Section 38 of Malaysia Arbitration Act 2005). In comparison to other alternative modes of private dispute resolution, arbitration is one of the renowned and preferred modes of dispute resolution techniques in the Malaysian construction industry. The said method is made available in all standard form of building contracts (Rajoo, 2008).

The development of arbitration in Malaysia can be traced back to the establishment of Arbitration Ordinance XIII of 1809. The ordinance stood for nearly 150 years until it was replaced by the Arbitration Act 1952 (1952 Act) which was modeled based on the UK Arbitration Act 1950 (Davidson \& Rajoo, 2006). Among others, the Malaysian 1952 Act was regarded as "controversial" due to active judicial intervention and the "statement of case" which actually provides means to delay proceedings. As a result from problematic issues in arbitration, the new Malaysia 
Arbitration Act 2005 (2005 Act) came into effect on the $14^{\text {th }}$ of March 2006. The 2005 Act adopted most of the broad principles outlined in the UNCITRAL Model Law on International Commercial Arbitration which is recognized by developed countries. Due to adversarial nature of arbitration, mediation is seen as an alternative to arbitration. Mediation is a means of settling dispute which involves an independent individual to assist the parties in dispute to reach a settlement (Murdoch \& Hughes, 2008). It is a consensual and non-adversarial procedure which produces the final result and encouraged as a precondition process prior to litigation (Cullinan, 2006; Bingham, 2009a).

Generally there are two types of mediation process: facilitative and evaluative approaches. However, the parties are free to adopt any type of the two types of mediation process to suit the nature of disputes and attitudes of disputants (Bingham, 2009b). Facilitative approach requires the mediator to facilitate the process and evaluative or intervention requires the said mediator to evaluate and propose a settlement. Some literature regarded evaluative mediation as conciliation or an extended version of mediation (Brooker, 2008).

\section{The Theoretical Framework}

\subsection{Disputes and Private Dispute Resolution}

Traditionally, resolving construction disputes are done through litigation. This can be confirmed by 72 cases related to building contract being reported by the Malayan Law Journal between 1997 and 2007 (Asniah, 2007) and the Current Law Journal which reported about 200 cases of construction related issues since 2004. Yet, today the litigation procedures have fallen into disrepute, particularly due to excessive costs, delays, procedural complexity and adversarial approach (Harmon, 2003; Jones, 2006).

The problematic issues in litigation are not new but have been apparent since the last decade and causing distortions in the business community worldwide (James, 2003). In the Malaysian context, it has been reported that as of July 2006 there are more than 300,000 civil cases including construction disputes pending in the Malaysian courts (New Straits Times, 18 June 2007). Furthermore, in May 2008, the Minister in the Prime Minister's Department stated that there are more than 900,000 unresolved cases in the lower courts and more than 91,000 at the High Court. He suggested that 
alternative methods of private dispute resolution may be the answer to the mounting backlog of civil cases nationwide (New Straits Times, 09 May 2008). As opposed to public dispute resolution, out of court or alternative methods of private dispute resolution are seen as the options to ensure efficient settlement of construction disputes (Thaveeporn, 2008). Given that these shortfalls will result in delays, complexities and expenses to the litigation process, there is a strong need for assisted settlement or other alternative methods of private dispute resolution apart from arbitration and mediation to be employed in the construction industry.

Due to the distinctive nature of the construction industry, the possibilities of generating disputes are high due to scientific or technical difficulties (Rajoo, 2008; Luen, 2006; El-adaway, 2008). Thus, the application of dispute resolution in both public and private projects seems to be unavoidable. Looking into the problematic issues in litigation as the public dispute resolution, there is a tendency by the construction industry to apply alternative methods of private dispute resolution (Leong, 2005). However, the application of arbitration in the Malaysian construction industry seems to be uncontested and pragmatically some believed that arbitration is the most suitable and well-known dispute resolution technique for settling Malaysian construction disputes (Rajoo, 2004). The main reason is the nature of the dispute resolution which is final and binding and its track record in the construction industry (Chan \& Suen, 2005). Since the establishment of Malaysia Arbitration Act 1952 and the latest 2005 Act, this mode of private dispute resolution is not new to the industry. Even so, one cannot deny that previous researches confirmed that there are negative reputations surrounding the practice of arbitration in Malaysia (Che Munaaim \& Loh, 2007; Abdul Aziz \& Kamal Halili, 2008). Thus, serious efforts are required to make private dispute resolution more effective and efficient.

\subsection{Arbitration and Mediation in the Malaysian Construction Industry}

Compared to the construction industry in UK, arbitration started to its lose popularity due to the development of cheaper and non-adversarial dispute resolutions such as adjudication and mediation (Reid \& Ellis, 2007; Brooker, 2007) and the development of a dispute board in big scale construction projects (Chapman, 2004; Ndekugri \& Russell, 
2006). However, other than mediation, other private dispute resolutions are not well publicized and utilized in the Malaysian construction industry.

In comparison to arbitration, other methods of private dispute resolution such as mediation and adjudication are relatively new to the Malaysian construction industry. Mediation has been introduced by PAM in its 1998 standard form and adjudication has been formed as part of its 2006 standard form. Similarly, CIDB in its 2000 edition standard form introduced mediation as one of the options for private dispute resolution. After more than ten years in the industry, mediation is not progressing at the same pace as arbitration; it is evident by the number of cases registered with various agencies. Between the year 2000 and 2008, numbers of mediation cases are very low compared to arbitration and no adjudication cases were reported (Table 1).

Table 1: Arbitration and Mediation Cases Registered With Various Agencies

Between 2000 and 2008

\begin{tabular}{|c|c|c|}
\hline Item & Source & Cases \\
\hline 1 & $\begin{array}{l}\text { Malaysian Mediation Centre } \\
\text { under the auspices of the } \\
\text { Malaysian Bar Council. }\end{array}$ & $\begin{array}{l}\text { Total } 155 \text { Mediation cases in which only four } \\
\text { construction mediation cases. }\end{array}$ \\
\hline 2 & $\begin{array}{l}\text { Malaysian Institute of } \\
\text { Architect (PAM). }\end{array}$ & $\begin{array}{l}\text { Total } 518 \text { construction arbitration cases } \\
\text { including one case in } 2008 \text { and no mediation } \\
\text { case so far. }\end{array}$ \\
\hline 3 & $\begin{array}{l}\text { Kuala Lumpur Regional } \\
\text { Centre for Arbitration } \\
\text { (KLRCA). }\end{array}$ & $\begin{array}{l}\text { Total } 126 \text { cases including } 27 \text { construction } \\
\text { cases. }\end{array}$ \\
\hline 4 & $\begin{array}{l}\text { Construction Industry } \\
\text { Development Board (CIDB). }\end{array}$ & $\begin{array}{l}\text { No reported case but CIDB was involved with } \\
\text { five cases acting as a mediator for both } \\
\text { government and private disputed projects. }\end{array}$ \\
\hline 5 & $\begin{array}{l}\text { Institution of Engineer } \\
\text { Malaysia (IEM). }\end{array}$ & $\begin{array}{l}\text { Total } 15 \text { construction arbitration cases until } \\
2007 \text {, no registered case in } 2008 \text { and no } \\
\text { mediation case. }\end{array}$ \\
\hline
\end{tabular}

Table 1 illustrates the number of construction arbitration and mediation cases registered with various agencies related to private dispute resolution between years 
2000 to 2008. Only Malaysian Mediation Centre reported four construction mediations and the rest of agencies seem not able to attract the construction participants to mediate.

In developed countries, mediation is very popular and recognized by the courts (Naughton, 2003; Brooker, 2007). Cases such as Dunnett v Railtrack ${ }^{l}$ where the court stated that "Skilled mediators are now able to achieve results satisfactory to both parties... which are quite beyond the power of lawyers and courts to achieve", and in the case of Hurst v Leeming ${ }^{2}$ where the court described that mediation is "at the heart of today's civil justice system." Naughton (2003) clarified that in the UK, those cases opened the floodgates and now the mediation is expressly recognized in the Commercial Court Guide, Chancery Guide, the Queen's Bench Guide and the Technology and Construction Court Guide.

However, a similar scenario does not appear to be happening in Malaysia. The Chairman of the Mediation Committee of the Bar Council expressed that "mediation has yet to be widely adopted by the business community in Malaysia" and she further confirmed that "greater acceptance of this alternative mechanism would also help clear the backlog of commercial cases waiting to be heard in court" (Bernama August 31, 2005). It has been suggested that the final and binding issues are the main problems in mediation and it would be more popular if mediation is placed on a statutory footing (Seng, 2006). Chapman (2004) clarified that in the United Kingdom, it has been reported that only a small percentage of cases went to arbitration and the remaining large percentage was settled by way of non-adversarial dispute resolution.

A research which was conducted by the Centre of Construction Law and Dispute Resolution, King's College London confirmed that majority of mediation cases was undertaken on the parties' own initiative; those advising the parties to construction disputes routinely consider mediation to try and bring about a resolution of the dispute; and the cost savings attributed to successful mediations were also significant, providing a real incentive for parties to consider mediation (Gould, et al., 2009). Thus, the concept of non-adversarial should be maintained as the best mechanism for dispute settlement.

${ }^{1}$ Dunnett v Railtrack [2002] All ER 850.

${ }^{2}$ Hurst v Leeming [2002] EWHC 1051 (Ch). 
There is no comprehensive empirical evidence and research is limited on the application of private dispute resolution in the Malaysian construction industry and how to ensure efficient settlement and improve private dispute resolution (El-adaway, 2008; Thaveeporn, 2008; Asniah, 2007; Chan \& Suen, 2005; Abdul Aziz \& Kamal Halili, 2008). As a result the industry continues to struggle to identify ways to resolve disputes equitably and economically. Some suggested that computer based mechanism be developed based on the historical data on construction disputes due to difficulty in finding dispute resolution practitioners (Cheng, Tsai, \& Chiu, 2009). Similarly, Brooker (2008) lucidly disclosed that there is still a shortage of empirical evidence which identifies the suitability and effectiveness of mediation for construction disputes. One of the reasons for such development is the areas of legal practice in the built environment, including construction law and dispute resolution has received little sustained scholarly attention (Chynoweth, 2009).

\subsection{The Research Methodology}

Mixed methods consist of quantitative research (cross sectional survey) and qualitative (in-depth semi structured interviews) were adopted for the research. Two research questions drawn for the investigations were:

- What are the construction variables which influence the application of arbitration and mediation?

- To what level is arbitration and mediation applied?

The respondents were $\mathrm{G} 7^{3}$ Building and Civil Engineering contractors in Malaysia registered with the Construction Industry Development Board (CIDB). G7 refers to the largest class of contractors which allowed to undertake projects in excess of MYR10

${ }^{3}$ Under Construction Industry Development Board (CIDB) contractors registration criteria, G7 contractors are those who have no limitation in tendering capacity, paid up capital worth MYR 750,000 (currency exchange rate USD\$ 1 equal to MYR 3.50) and minimum personnel / resources requirement: one Group A (Degree holder in construction related fields) and one Group B (Diploma holder in construction related fields or other degree holder with experience in construction works) both with minimum five years experience or two Group A (one of whom must have 5 years experience) (Source: CIDB, The Construction Industry Directory 2004-2005). 
million or USD\$ 35 million. One thousand questionnaires were sent out to the sampling frame of 2834 and the response rate was $23.1 \%$ (Table 2). Selection of target group was made based on the track records and years of establishment of the organization as reported in the Malaysian Construction Industry Directory 2004-2005 published by CIDB. Quantitative data was analyzed using non-parametric statistics using the SPSS Version 14. Of the 231 respondents, 30 with experience in arbitration and 20 in mediation were identified but only 30 of these were willing to be interviewed (18 with experience in arbitration and 12 in mediation). Subsequently, the qualitative analyses were carried out using the ATLAS.ti 5.0 to ensure internal validity of the findings.

Table 2: Sampling Frame

\begin{tabular}{|c|c|c|c|c|c|c|c|}
\hline \multirow{2}{*}{\multicolumn{2}{|c|}{ State }} & \multicolumn{2}{|c|}{$\begin{array}{c}\text { Potential } \\
\text { Respondents }\end{array}$} & \multicolumn{2}{|c|}{$\begin{array}{c}\text { Respondents } \\
\text { (stratified } \\
\text { sampling) }\end{array}$} & \multicolumn{2}{|c|}{$\begin{array}{c}\text { Actual } \\
\text { Respondents }\end{array}$} \\
\hline & & $\mathrm{N}$ & Percent & $\mathrm{N}$ & Percent & $\mathrm{N}$ & Percent \\
\hline 1 & Johor & 144 & $5 \%$ & 51 & $5 \%$ & 7 & $3 \%$ \\
\hline 2 & Kedah & 125 & $4 \%$ & 44 & $4 \%$ & 2 & $1 \%$ \\
\hline 3 & Kelantan & 100 & $4 \%$ & 35 & $4 \%$ & 0 & $0 \%$ \\
\hline 4 & Kuala Lumpur & 716 & $25 \%$ & 254 & $25 \%$ & 62 & $27 \%$ \\
\hline 5 & Melaka & 37 & $1 \%$ & 13 & $1 \%$ & 1 & $0 \%$ \\
\hline 6 & Negeri Sembilan & 53 & $2 \%$ & 19 & $2 \%$ & 3 & $1 \%$ \\
\hline 7 & Pahang & 72 & $3 \%$ & 25 & $3 \%$ & 3 & $1 \%$ \\
\hline 8 & Pulau Pinang & 116 & $4 \%$ & 41 & $4 \%$ & 6 & $3 \%$ \\
\hline 9 & Perak & 75 & $3 \%$ & 26 & $3 \%$ & 4 & $2 \%$ \\
\hline 10 & Perlis & 18 & $1 \%$ & 6 & $1 \%$ & 0 & $0 \%$ \\
\hline 11 & Sabah & 207 & $7 \%$ & 73 & $7 \%$ & 5 & $2 \%$ \\
\hline 12 & Sarawak & 179 & $6 \%$ & 63 & $6 \%$ & 5 & $2 \%$ \\
\hline 13 & Selangor & 883 & $31 \%$ & 312 & $31 \%$ & 127 & $55 \%$ \\
\hline 14 & Terengganu & 109 & $4 \%$ & 38 & $4 \%$ & 4 & $2 \%$ \\
\hline 15 & No answer & & & & & 2 & $1 \%$ \\
\hline To1 & & 2834 & $100 \%$ & 1000 & $100 \%$ & 231 & $100.0 \%$ \\
\hline
\end{tabular}




\subsection{Cross Sectional Survey}

Descriptive statistics using the Bivariate analysis using Chi-Square (CS) Tests i.e., the test for independence and correlation analysis (measure of association) using Cramer's $\mathrm{V}$ (CV) together with Contingency coefficient (CC) test for nominal data and Spearman's Rank (SR) order test for ordinal data were applied.

Out of the total of 231 responses, $10 \%$ of the construction organizations applied mediation. Figure 1 indicates that there is no significant difference in term of the application of mediation and the years of establishment of the organization. Those that have been established more than 21 years applied mediation less than $3 \%$, and similar percentage can be seen for those established between 16 to 21 years and 11 to 15 years respectively. Comparatively, smaller percentage of less than $2 \%$ for those established between 6 to 10 years. Comparatively, 6.8\% of those applied arbitration were established for more than 21 years and those established for between 11 to 15 years applied arbitration less than 4\%. It seems that those were established 10 years and below were reluctant to apply arbitration as compared to mediation.

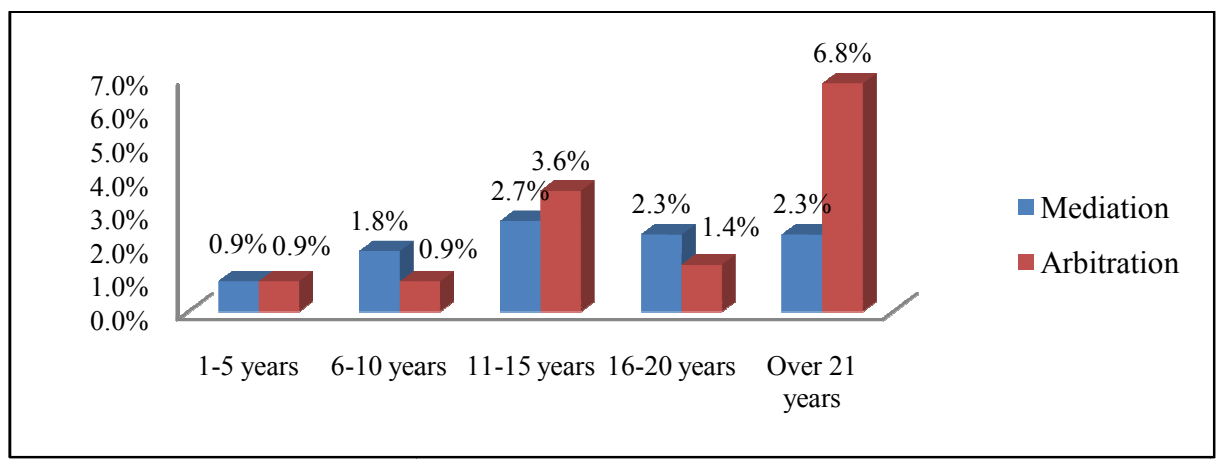

\section{Figure 1: Years of Establishment of the Construction Organizations and Application of Private Dispute Resolution}

As depicted in Figure 2, a significant percentage of respondents reported that their organizations applied mediation between one or two times throughout the years of establishment. Obviously, the respondents/organizations may want to try mediation and to observe whether it is successful as a means of dispute settlement. As a result, some might agree with the efficiency of mediation when $4.2 \%$ of those established for between 11 to 20 years applied mediation between three to five times and $3.6 \%$ of those 
established for 10 years and below applied mediation for more than five times. A similar trend was observed for the years of experience for individual respondents and the application of mediation in term of quantity as illustrated in Figure 3. The highest percentage of $6.1 \%$ applied mediation between one to two times over the last 21 years and $3.6 \%$ of the same group applied mediation more than five times. It seems that those who applied mediation more than five times were comfortable with the dispute resolution. Furthermore, analyses of relationship indicated that there was no significant relationship between the variables (applications of mediation and years of establishment, contract price and project duration) since Chi Square $p>\alpha=0.05$. Thus, the application of mediation was not influent by the years of establishment, contract price and project duration (Table 3 ).

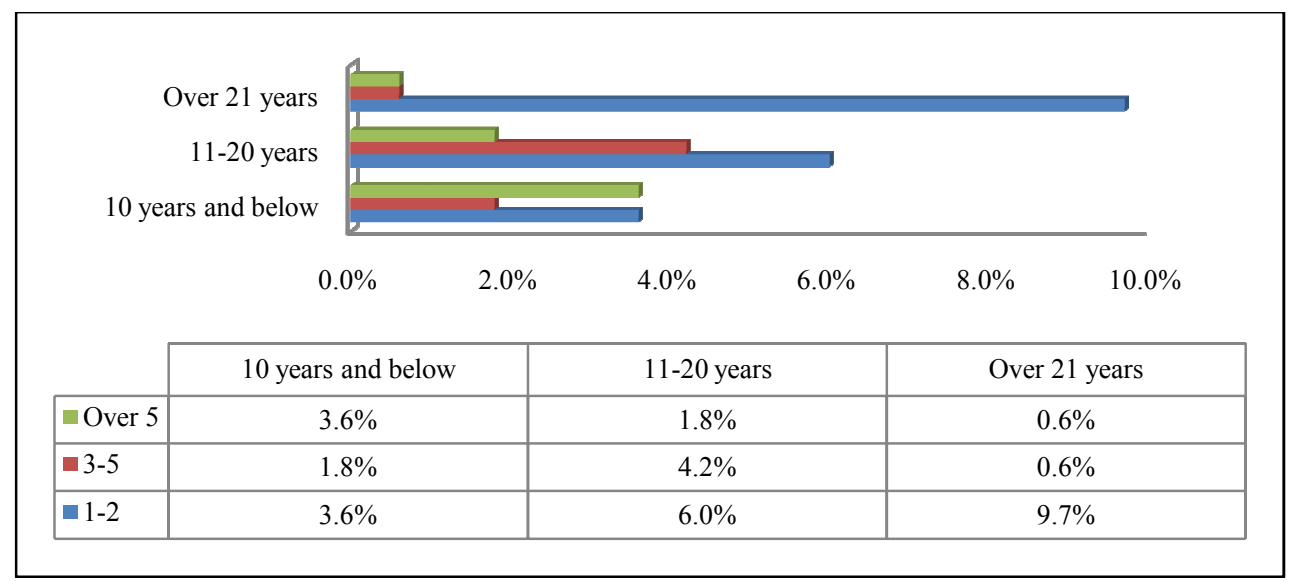

Figure 2: Years of Establishment of the Construction Organizations and Quantity of Mediation 


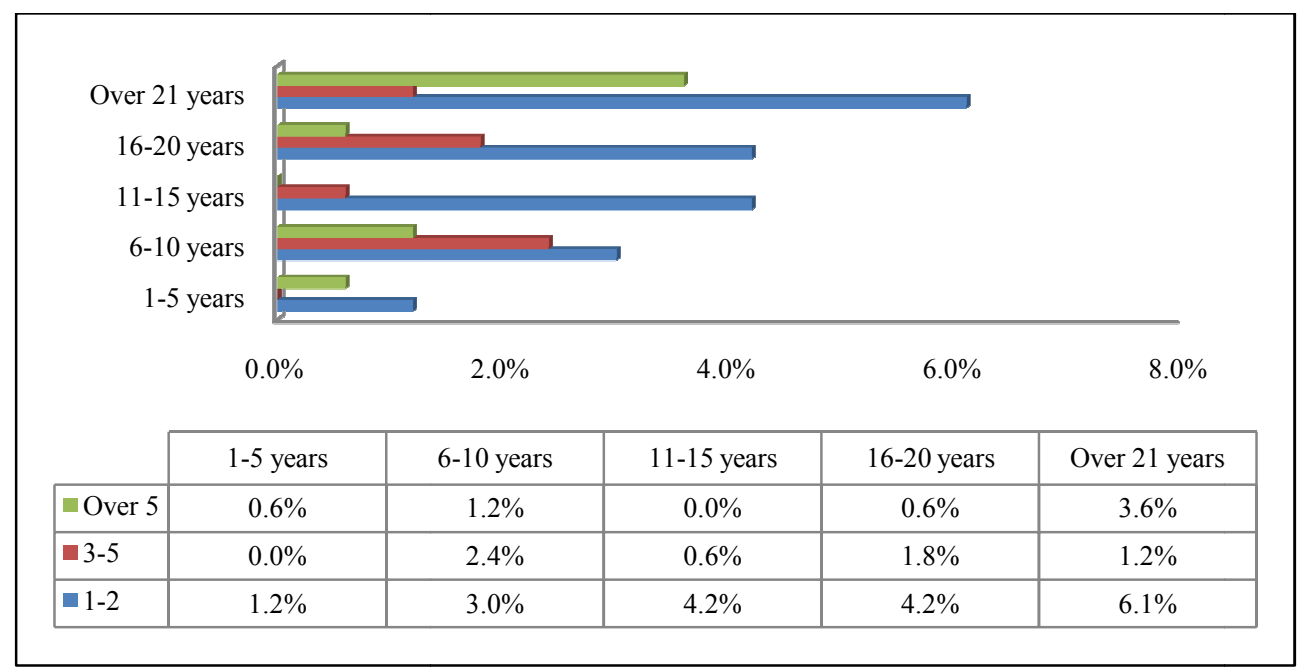

Figure 3: Years of Experience and Quantity of Mediation

Table 3: Application of Mediation (Measure of Association)

\begin{tabular}{|c|c|c|c|c|c|}
\hline \multicolumn{2}{|r|}{ Variables } & Chi-Square & Cramer's V & $\begin{array}{c}\text { Contingency } \\
\text { Coefficient }\end{array}$ & \multirow{2}{*}{$\begin{array}{c}\text { Spearman } \\
\text { Rank }\end{array}$} \\
\hline 1 & Years of Establishment & 0.84 & & & \\
\hline 2 & Contract Price & 0.47 & & & \\
\hline 3 & Project Duration & 0.31 & & & \\
\hline 4 & Satisfactory Application & 0.00 & 0.77 & 0.74 & \\
\hline 5 & Unsatisfactory Application & 0.00 & 0.71 & 0.71 & \\
\hline 6 & Recommended Application & 0.00 & 0.69 & 0.70 & \\
\hline 7 & Respondents Designation & 0.04 & & & -0.14 \\
\hline
\end{tabular}

The quantitative findings indicated that the application of mediation was observed to be considerably high for higher contract value and the highest frequency of application was still between one or two cases and the application of mediation was observed to be low for considerably low valued contract. In terms of project duration, projects with less than three years were observed to be more active in applying mediation.

Based on the quantitative findings discussed above, there was inconsistency between the numbers of cases registered with various agencies as depicted in Table 1. Apparently, due to the characteristics of private dispute resolution which is confidential 
and private, the parties may not want it to be administered or interfered by professional and government agencies. Thus, maintaining the confidentiality of the process. Even so, looking into the application of mediation as discussed from the quantitative research, the level of application is still low. Thus, further data is required to determine the reasons for underutilization.

\subsection{Semi Structured Interviews}

Results from semi-structured interviews indicated that the appropriateness of mediation depending on the commitment and consistency of disputed parties to resolve the issue and to "accelerate" the process. The "relationship" between the disputing parties will be the deciding factor to determine whether adversarial or non-adversarial dispute resolution will be appropriate. For instance, if there is tendency for the parties to maintain the current level of relationship, then mediation may be appropriate. Otherwise, arbitration may be suitable. However, in terms of the disputed amount, both the quantitative and qualitative analyses indicated no strong relationship with the methods of dispute resolution. It was conceived that, the perception that "arbitration is appropriate for disputes

hich related to large amounts of money" and mediation for "small amounts" might not be accurate.

Substantial percentage of $58 \%$ believed that the choice to mediate was appropriate compared to arbitration (33\%). However, $42 \%$ believed mediation was inappropriate and $44 \%$ believed the same with arbitration (Figure 4 ). Therefore, as a whole many of them believed that the private dispute resolution was not appropriate (Figure 4). Even so, $75 \%$ of those applied mediation recommended mediation to be fully utilized as appropriate means, while $29 \%$ agreed the same for arbitration (Figure 5). One of the reasons for recommended mediation was minimum payment for the process of mediation as depicted in Figure 6. Thirty one percent of those who applied mediation without payment to mediator were instances when mediator was appointed due to close relationship between the disputed parties. Comparatively, 19\% of those applied arbitration has to spend MYR 500K or USD\$ $143 \mathrm{~K}$. Looking at the trend in Figure 6 the overall cost of mediation was considered cheap. 


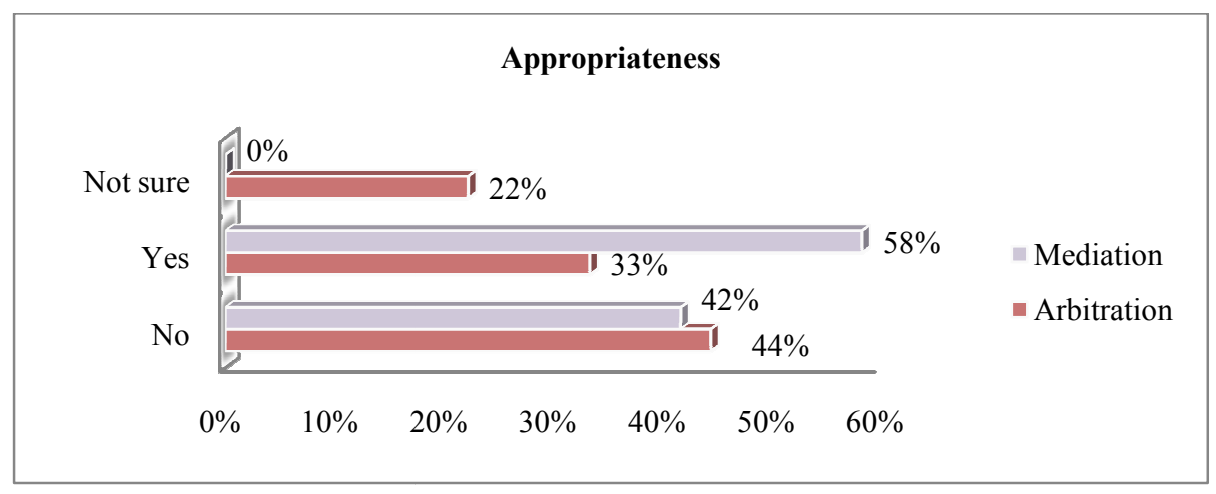

Figure 4: Appropriateness of Private Dispute Resolution in Settling Construction Disputes

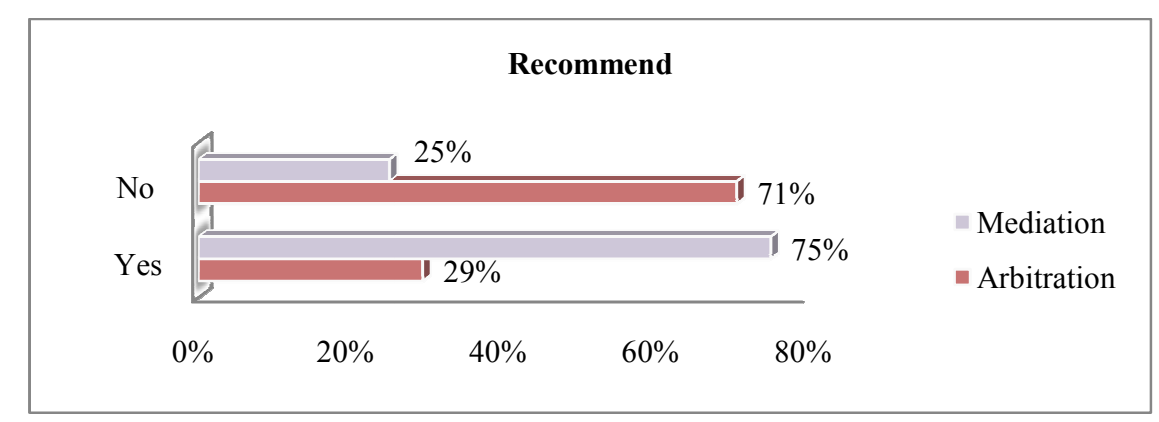

Figure 5: Recommended Private Dispute Resolution as the Best Way to Resolve Construction Disputes 


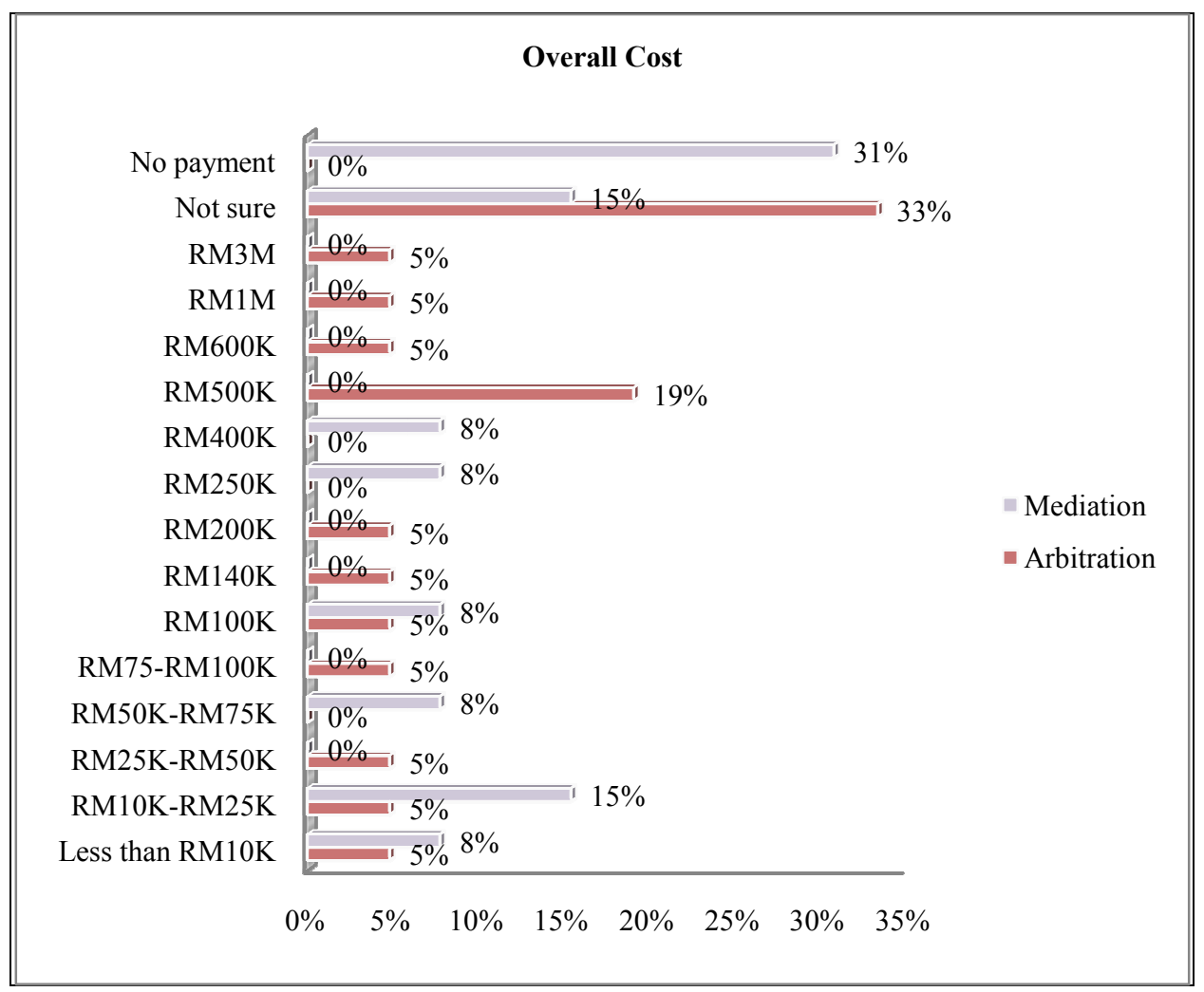

Figure 6: Overall cost of Private Dispute Resolution

As for problems faced by the respondents in arbitration and mediation, Figure 7 presents that $33 \%$ of respondents had experienced mediation without major problems while only $6 \%$ agreed the same for arbitration. However, $25 \%$ reported that they have had problems of co-operation by the other party in the mediation. Comparatively, timing issues were the most problematic in arbitration (21\%), together with cost related issues such as amount at stake (18\%) and fees of the arbitrator (15\%). This is consistent with the main reasons for low preference over the dispute resolution. 


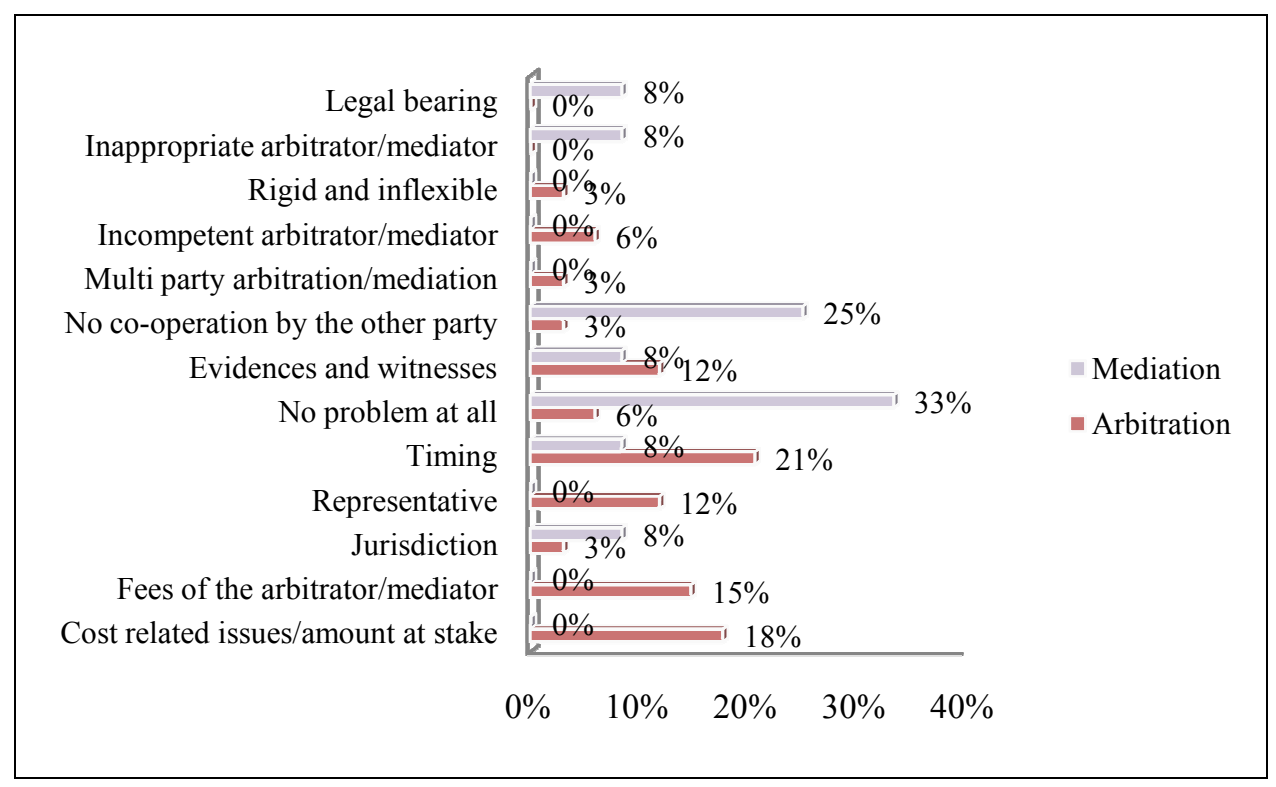

\section{Figure 7: Problems in Arbitration and Mediation Process}

As depicted in Figure 7, time and cost were the main reasons why the respondents felt arbitration was inappropriate. Comparatively, most respondents agree that time and cost related issues were not problematic in mediation. Therefore, cases with low quantum disputed and simple issue may not be appropriate for arbitration; instead mediation might be the best option. However, not all arbitration cases were expensive and time consuming as many cases were resolved in less than three years. Knowledge in the dispute resolution together and commitment to resolve disputes is crucial to ensure appropriateness of any private dispute resolution since there is a tendency to misuse and abuse the process.

The "adversarial" nature of arbitration appears to be more inappropriate for the Malaysian construction industry. In terms of its process, an impartial arbitrator is expected to dispose the issue by looking into both expressed and implied terms of the contract. Professionalism tends to be demanded more in arbitration compared to mediation. Comparatively, a win-win situation is expected in mediation and the mediator is regarded as a middle man to facilitate the process. However, non-binding mechanism of mediation emerge as one of the the most inappropariate compared to final and binding arbitrator's award. To avoid risk of inappropriate selection of dispute 
resolution methods, it is suggested to apply mediation, arbitration and court in stages since there are pros and cons for each of the method.

\subsection{Triangulated Analyses and Findings}

Findings from the research were consistent with the previous researches in the area. Abdul Aziz \& Kamal Halili (2008) conducted a research on the awareness on the process of arbitration in public projects. A survey had been conducted in 2007 involving 302 respondents from various backgrounds. Among others, the research revealed ten negative attitudes towards arbitration which were the obstacles towards further active development of arbitration in the country:

1. The respondents believed that arbitrator's award was inaccurate.

2. The respondents considered that the process of arbitration was not clear.

3. The location for arbitration was very far. For instance, the provisions in PWD form of contract states that arbitration to be conducted at Regional Centre for Arbitration (RCAKL).

4. They were not confident with the process of arbitration.

5. They worried that the process of arbitration was unmanageable.

6. They believed that arbitration process would delay.

7. The cost of arbitration was high.

8. They were not confident with the arbitrator.

9. They believed that the result (arbitrator's award) would not be accepted by the parties.

10. Lack of understanding in arbitration.

The outcome of the research suggested that arbitration was not a favorable mechanism for construction disputes due to lack of confident, understanding, time factor and cost issues. Thus, mediation might be the answer for efficient settlement of construction disputes. Similar scenario took place in the construction industry in UK in the late 1970 s and early 1980 s when arbitration started to lose its popularity as stated by Dancaster (2008). Consistently, Fullerton (2005) claimed that it has evolved to the point where it was no longer efficient than litigation because it has been manipulated by lawyers and turned it into something similar to litigation. Thus, it defeated the purpose to arbitrate. 
The main reason to arbitrate is to avoid being stranded in court and feel uncomfortable over the process of litigation. However, due to incompetency and lack of awareness and understanding, construction participants tend to employ lawyers to represent their case. As a result, same problems will emerge.

In the late 1990 and early 2000, empirical evidence by Brooker \& Lavers (2002) confirm that mediation was started to be utilized and accepted in the UK due to the overall use of $16 \%$ out of total 128 respondents (construction and commercial lawyers). They further suggested the result provides compelling evidence that alternative mechanism of dispute resolution is being taken up by some sectors of legal practice. Other than that the research indicates:

- $77 \%$ settlement rate.

- $\quad 90 \%$ were satisfied with the process.

- $84 \%$ expressed satisfaction with the speed of mediation.

- $\quad 69 \%$ satisfied with the cost and $73 \%$ satisfied with the mediator.

- $50 \%$ recommended the process frequently and $63 \%$ disagree with the statement that proposing mediation is a sign of weakness.

- $80 \%$ of the respondents had made a proposal of mediation to the other side.

Clearly, commercial and construction lawyers in favor of mediation. Thus, the statement that mediation is not well supported and accepted by lawyers may not be correct. In a recent study by Gould, et al. (2009) further reinforced the findings by Brooker \& Lavers (2002) and the quantitive analyses discussed above when they concluded that:

- Mediation can result in significant costs savings, $76 \%$ resulted in cost savings of over $£ 25,000$;

- Even where mediation did not result in a settlement, the research indicates that mediation was not always regarded as negative, it was often still viewed as beneficial, allowing an element of a dispute to be settled, narrowing the disputes or contributing to a greater understanding of the other side's case.

- Settlement rates were high, majority of respondents who had used mediation said it resulted in a settlement and majority of mediations were undertaken at 
the parties' own initiative (more than $70 \%$ ) and not as a result of court suggestion or order.

- Even where mediation was unsuccessful, 91\% occurred as a result of the parties' own initiative.

- In terms of timing for mediation, the parties did not wait until the hearing was imminent before trying and settling the dispute.

Gould, et al. (2009) lucidly clarified that similar researches the USA and UK consistently indicate greater acceptation of mediation in the construction industry. Similarly, findings of this research indicate that mediation tends to be a better proposition to settle the dispute when terms time and cost is the critical element. The factors which contribute to effective private dispute resolution methods culminated from the quantitative and qualitative analyses were:

1. Appointment of practitioner such as arbitrator or mediator should be based on the nature of the dispute, highly experience and well versed in construction contracts and law and the appointment should be made at the initial stage such as during pre-contract.

2. Pre-dispute resolution preparation, such as to ensure sufficient documentations, determination of appropriate mode either adversarial (arbitration) or nonadversarial (mediation) by looking into the background and attitude of the parties and disputed amount at stake.

3. During dispute resolution process, a reasonable amount of documentation and presentation, spirit of the parties to resolve dispute fast, abide with contractual time, presentation of case by way of chronological events, appointment of experts to assist the process and participation of working level staff is crucial to ensure successful process of dispute resolution.

4. Prior to actual settlement, the parties may predict the outcome and withdraw from the process to avoid further losses.

5. The parties need to be flexible in the sense of accepting the final decision and fulfill obligations apportioned in the settlement. 
Underlined by quantitative and qualitative analyses discussed above, further recommendations to improve mediation in the construction industry are:

1. An establishment of a framework for efficient dispute resolution to include mediation as one of the main dispute resolution prior to adversarial dispute resolution.

2. Amendment of the standard form of contract by adding mediation as one of the options for private dispute resolution.

3. Upgrade the current practice and procedure of mediation in order to ensure successful outcome with at minimum cost, simple or user friendly and effective process.

4. Active promotion and education by both professional and academic institutions.

5. Impartial and non-profit organization to administer and oversee mediation.

6. Establishment of the Malaysia Construction Industry Courts to dispose issues relating to construction disputes and court-annexed mediation should be encouraged and regulated.

7. Induction course on construction disputes and settlement using mediation to be conducted for Project Managers.

8. Final and binding and enforceable mechanism need to be part of mediation settlement.

\section{Conclusion}

Dispute is common in the construction industry due to the complexities and magnitude of works. As a result, the application of dispute resolution is unavoidable. As to the nature of non-adversarial in mediation, most of the construction participants regarded that it was appropriate for the industry. However, this research indicated that very small percentage applied mediation and there was no strong relationship between the application of mediation in terms of numbers and years of establishment; contract price; project duration; resolved cases and years of experience.

Appropriateness of mediation is largely dependent on the disputing parties' commitment and consistency to accelerate the process. The relationship of the disputed parties is the deciding factor to apply mediation. Empirical evidences indicate that 
mediation is cheaper than adversarial private dispute resolution such as arbitration and most respondents believed that the choice to mediate was right compared to arbitrate. To ensure successful process of mediation, careful appointment of mediators; sufficient documents to back-up the claims; spirit to resolve and flexibility are crucial.

In order to improve and utilize mediation in the construction industry, efforts from the government agencies, professional bodies, industry bodies and academic institutions are required and further action is needed to promote and support mediation such as the establishment of construction industry court and court annexed mediation, upgrade mediation in term of formulating cheaper, simpler or user friendly and effective process and make good any potential problems that will or may arise in all stages of the mediation process.

\section{References}

Abdul Aziz, H., \& Kamal Halili, H. (2008). Satu Survei Kesedaran Proses Timbang Tara Dalam Projek Pembinaan Kerajaan. In A. Y. Sakina Shaik, C. N. Anisah, Z. Zinatul Ashikin, Y. Noor Inayah, \& M. A. Hasani, Undang-Undang Dalam Era Teknologi (pp. 420-448). Kuala Lumpur: Fakulti Undang-Undang Universiti Kebangsaan Malaysia.

Asniah, B. (2007). The Profile of Construction Disputes. Johor Bahru: University of Technology Malaysia.

Bingham, T. (2009a, August 5). Mediation Privacy. Retrieved September 8, 2009, from Tony Bingham's Web Site: http://www.tonybingham.co.uk/Default.htm

Bingham, T. (2009b, August 5). What Goes on in Mediation Stays in Mediation. Retrieved September 9, 2009, from Tony Bingham's Web Site: http://www.tonybingham.co.uk/Default.htm

Brooker, P. (2008). An Investigation of Evaluatibe and Facilitative Approaches to Construction Mediation. Structural Survey, 25 (3/4), 220-238.

Brooker, P. (2007). An Investigation of Evaluative and Facilitative Approaches to Construction Mediation. Emerald, 25 (3/4), 220-238.

Brooker, P., \& Lavers, A. (2002). Commercial Lawyers' Attitudes and Experience With Mediation. Web Journal of Current Legal Issues (4).

Chan, E. H., \& Suen, H. C. (2005). Dispute Resolution Management for International Construction Projects in China. Emerald, 589-602.

Chapman, P. (2004). Dispute Board. King's College London.

Che Munaaim, M., \& Loh, P. (2007). Stepping outsie the Traditional Roles: The Quantity Surveyor and Adjudicator. Quantity Surveying International Convention (pp. 281-290). Kuala Lumpur: Construction Industry Development Board.

Cheng, M.-Y., Tsai, H.-C., \& Chiu, Y.-H. (2009). Fuzzy Case-Based Reasoning for Coping With Construction Disputes. An International Journal Expert Systems with Applications , 4106-4113. 
Chynoweth, P. (2009). Legal Scholarship: A Discipline in Transition. International Journal of Law in the Built Environment , 1 (1).

Cullinan, P. (2006, October). Focus on Mediation. Tunnels and Tunnelling International, 33-35.

Dancaster, C. (2008). Construction Adjudication in the United Kingdom: Past, Present, and Future. Journal of Professional Issues in Engineering Education and Practice , 134 (2), 204-208.

Davidson, W., \& Rajoo, S. (2006). The New Malaysian Arbitration Act 2005. Arbitration , 3 (72), 257-264.

Edwards, P., \& Shaoul, J. (2003). Partnerships: For Better, For Worse? Accounting, Auditing and Accountability Journal , 16 (3), 397-421.

El-adaway, I. H. (2008). Construction Dispute Mitigation Through Multi-Agent Based Simulation and Risk Management Modeling. Iowa State University.

Forster, C. M., \& Jivan, V. (2008). Public Interest Litigation and Human Rights Implementation: The Indian and Australian Experience. Asian Journal of Comparative Law , 3 (1), Article 6.

Fullerton, R. (2005). Searching for Balancein Conflict Management:The Contractor's Perspective. Dispute Resolution Journal, 60 (1).

Gould, N., King, C., Hudson-Tyreman, A., Betancourt, J. C., Ceron, P., Lugar, C., et al. (2009). The Use of Mediation in Construction Disputes. King's College London and The Technology and Construction Court, The Centre of Construction Law and Dispute Resolution. London: Society of Construction Law .

Harmon, K. (2003). Dispute Review Boards and Contribution Conflicts: Attitutes and Opinions of Construction Industry Members. Nova Southeastern University.

Jones, D. (2006). Construction Project Dispute Resolution: Options for Effective Dispute Avoidance and Management. Joutnal of Professional Issues inEngineering Education and Practice , 3 (132), 225-235.

Leong, C. Y. (2005, November 16). Mediating Construction Disputes. Kuala Lumpur, Malaysia.

Luen, L. K. (2006). Litigation in Construction Contracts. Mediation, Adjudication, Litigation and Arbitration in Construction Contracts. Kuala Lumpur: MySeminar Sdn Bhd.

Murdoch, J., \& Hughes, W. (2008). Construction Contracts Law and Management (4th Edition ed.). Abingdon, Oxon: Taylor and Francis.

Naughton, P. (2003). Mediators are Magicians - A Modern Myth? London: Society of Construction Law.

Ndekugri, I., \& Russell, V. (2006). Disputing the Existence of a Dispute as a Strategy for Avoiding Construction Adjudication. Engineering, Construction and Architectural Management, 13 (4), 380-395.

Rajoo, S. (2004). Law, Practice and Procedure of Arbitration. Kuala Lumpur: Malayan Law Journal.

Rajoo, S. (2008). Master Builders. Arbitration in the Construction Industry, pp. 72-76.

Reid, A., \& Ellis, R. C. (2007). Common Sense Applied to the Definition of A Dispute. Emerald , 25 (3/4), 239-252.

Seng, L. S. (2006). Mediation in Construction Contracts. Mediation, Adjudication, Litigation and Arbitration in Construction Contracts. Kuala Lumpur: Current Law Journal. 
Stitt, A. J. (2004). Mediation: A Practical Guide. London: Cavendish Publishing. Thaveeporn, P. (2008). Universal Prediction Model for Construction Litigation. Illinois Institute of Technology.

Zulhabri, I., \& Torrance, J. V. (2006). Efficient Risk Allocation in the Project Finance: Analysis of Literature Review. International Conference in the Built Environment (pp. 397-405). Kuala Lumpur: University of Technology MARA. 